\title{
THE DANGEROUS INSTRUMENT DOCTRINE
}

The dangerous instrument doctrine which has often been used as a basis of liability, particularly in the case of the operation of steam railroads, is an anomalous one and few courts seem to have attempted any careful limitations upon its application. The rule has been stated as follows: "Whenever the master, having under his control some specially dangerous agency or instrumentality, and which he is therefore under special obligation to keep with care, confides this duty to his servant or agent, he will be responsible if the duty be not performed, whether through the negligence or the wantonness or the malice of his servant or agent."'1

It is to be noticed that the basis of liability here is entirely different from that in ordinary cases of master and servant. In the law of master and servant the master is held only when it can be shown that an injury was caused by his servant while acting within the scope of his employment, and the master is relieved from liability by showing that the servant, who caused the injury, was upon a "frolic of his own." 2 The rule as applied in ordinary cases of master and servant is that stated in M'Manus $v$. Crickett: ${ }^{3}$ "When a servant quits sight of the object for which he is employed, and without having in view his master's orders pursues that which his own malice suggests, he no longer acts in pursuance of the authority given him, and . . . his master will not be answerable for such act." The dangerous instrument doctrine, if it is to be considered as a rule upon which the master is to be held, is opposed to this fundamental principle of the law of agency; for the very idea for which it stands is that the master shall be held, even though the servant has for the time being entirely lost sight of his master's business and is only carrying out his own wishes and designs. In cases decided on the dangerous instrument doctrine, the master is held liable regardless of the fact that the servant is acting without having any purpose or intent to further the business in which he is employed.

1 Mechem, Agency (2d ed.) sec. 1945.

2 Joel v. Morison (r834) 6 C. \& P. 50r.

3 (1800) I East, 106. 
Undoubtedly, many courts have attempted to apply both the ordinary rules of liability of a master for the torts of his servant and the doctrine of dangerous instruments without realizing that the two principles are inconsistent, ${ }^{4}$ and the moment it is sought to put the master's liability upon the basis of acts done within the scope of the servant's employment, the doctrine of dangerous instruments is entirely unnecessary, since the ordinary rule of torts as found in the law of master and servant will determine the case. It is sometimes sought to put the liability upon the basis that the master has made the custody of the thing the servant's duty, and that therefore any improper use made of it by the servant is merely negligence within the scope of his employment. ${ }^{5}$ The necessary conclusion from such reasoning would seem to be that it would be impossible for a servant thus employed ever to go upon a "frolic of his own" and depart from the master's business. "It is true that when using such an instrument for his own purposes to injure or frighten others or to amuse himself the servant is not keeping it safely; but it is also true that in the act he does he is not representing the master, and the injury he inflicts is the result of that act and not of a mere failure to properly keep . . . The distinction is not technical merely, but is made necessary by the reason upon which the rule respondeat superior rests." ${ }^{\prime}$ Although in one early case ${ }^{7}$ the court made the master liable because he had entrusted a horse and carriage to his servant, this idea has been entirely overthrown, and the master is clearly relieved from liability under ordinary circumstances if the servant uses for a purpose of his own entirely the very article with which he was entrusted and which he was to care for. ${ }^{8}$ If the idea of entrusting the servant with the custody of the thing is to be applied at all, as fixing the master's liability, it would seem that one who entrusts his

4 Johnson v. C. R. I. \& P. Ry. Co. (I9I3) I57 Ia. 738; Evers v. Krouse (I904) 70 N. J. L. 653; Alsever v. Mimnesota etc. Ry. Co. (I902) II5 Ia. 338; Black v. Rock Island A. \& L. R. R. Co. (I909) 125 La. I01; Merschel v. Louisville, etc. R. R. Co. (I905) I2I Ky. 620; Barmore v. Vicksburg, etc. Ry. Co. (1904) 85 Miss. 426.

'Euting v. C. \& N.W. Ry. Co. (1902) II6 Wis. I3.

${ }^{\circ}$ Galveston, etc. Ry. Co. v. Currie (1906) 100 Tex. 136.

TSleath v. Wilson (1839) 9 C. \& P. 607.

${ }^{8}$ Storey v. Ashton (1869) L. R. 4 Q. B. 476 ; St. L. S. W. Ry. Co. v. Harvey (1906) I44 Fed. 806; Slater v. Advance Thresher Co. (1906) 97 Minn. 305. 
servant with a dangerous instrument is liable because of its dangerous character, even though the servant uses it entirely outside the scope of his employment, and upon a "frolic of his own." Though the master is sometimes liable for such misuse of the dangerous instrument, it is doubtful whether any court would carry the doctrine so far as to hold the master liable at all times and under all circumstances because of this entrusting. ${ }^{9}$

In this connection it is not proposed to discuss whether the doctrine of dangerous instruments is sound, or whether, if sound, it has been properly applied in all cases. So far as courts have adopted it, what are the limits of its application? If the master is not liable for merely entrusting something to his servant with which he has done an injury, but is liable because the thing entrusted is inherently dangerous, what are the limits of his liability for its misuse? To make the master liable for its misuse, or the consequences of its misuse by the servant to whom he has entrusted it, at any time or place, would certainly be carrying an extreme doctrine beyond any reasonable limits and would seem to place an arbitrary and unreasonable liability upon him.

A number of theories have been advanced as explaining the basis of liability in the dangerous instrument cases. It has been suggested in several cases ${ }^{10}$ that the liability is similar to that established in the case of Fletcher $v$. Rylands;", namely, "that the person who for his own purposes brings on his land, and collects and keeps there, anything likely to do mischief if it escapes, must keep it in at his peril." The liability has also been compared to that placed upon the owner or keeper of vicious or wild animals, ${ }^{12}$ an idea suggested in Fletcher $v$. Rylands as the basis of that decision. But in each case the only resemblance to the dangerous instruments doctrine is that a liability seems to be put upon a person apart from negligence such as is required to be shown in other classes of cases. Though such liabilities are

9 Totedo, etc. Ry. Co. v. Harmon (1868) 47 Ill. 298. In attempting to place some limit upon the master's liability the court emphasized the time and place of entrusting. If, "When employed in the discharge of his duty, or while engaged in operating their engines and machinery on their road . . . he wilfully perverts such agencies to the purpose of wanton mischief and injury, the company should respond in damages."

${ }^{10}$ Cleveland, T. \& V.R.R. Co. v. Marsh (1900) 63 Oh. St. 236; Penas v. C. M. \& St. P. Ry. Co. (1910) 112 Minn. 203.

11 (1866) L. R. I Ex. 265; affirmed (1868) L. R. 3 H. L. Cas. 330.

12 Penas v. C. M. \& St. P. Ry. Co., supra. 
not numerous, it does not follow that they are all based upon the same principles, or governed by the same law, or limited in the same manner. A comparison has also been suggested with the "turn table" cases. ${ }^{13}$

Except for the fact that the liability for injury is not based on negligence as ordinarily applied, it seems difficult to compare the rule of Fletcher $v$. Rylands with the dangerous instrument doctrine, or to find in such comparison any limitation upon liability which may be applied in this peculiar class of cases. No very great resemblance can be made out between the storage of such a force as water in a reservoir and the ownership of a railroad torpedo. Clearly every possessor of a raiload torpedo or other like explosive is not ordinarily held to liability on the principle set forth in Fletcher $v$. Rylands. When it comes to such acts as blowing the whistle of or letting off steam from a locomotive engine, any possible comparisons seem even more remote. So also, the cases of injuries resulting from the vicious propensities of animals, or the escape of wild animals do not bear any striking resemblance to injuries from wilful misuse of the whistle, or steam exhaust of an engine, or the improper use of a railway torpedo. Neither does the Fletcher $v$. Rylands rule, or any rule of law concerned with the keeping of animals, aid in any way in determining what are dangerous instruments, or explaining the apparent inconsistencies in the decisions. But none of these suggestions have been followed out by the courts to aid in fixing limits to the master's liability for the misuse by his servants of dangerous instruments. The so-called "turn table" cases $^{14}$ presenting the idea of attractive nuisances, might suggest a comparison in cases where the railroad company allows a torpedo to be exposed so that a child finds it and is later injured while examining it. But the idea of these cases does not seem to be applicable, or to account for the result as in cases where the injury is done by the deliberate act of a servant done for his own purpose and without reference to carrying out his master's business. It is true that there is running through the cases the general idea that one who keeps something which is particularly dangerous, and which is especially apt to do injury to third persons, has placed upon himself a duty of special care to prevent it from doing injury. In this respect, the one who

13 Harriman v. Pittsburg, etc. Ry. Co. (1887) 45 Oh. St. II.

14 Cooley, Torts (3d ed.) p. I270, n. 38. 
entrusts a dangerous instrument to his servant is held to a somewhat similar liability, in that he is held to a standard of liability which is not measured by the ordinary responsibility of a master for the acts of his servant, as established in the law of agency. If the duty is not performed, it is immaterial that the servant acted outside the scope of his employment in making improper use of the instrument; for the master may nevertheless be held. But the courts have not carried out the analogy further than this, and have not placed the master's liability upon the results of such cases further than to suggest and sustain the general proposition, that one may have a duty of extreme care and be held to an unusual liability.

Though the entrusting of the servant with the dangerous instrument is often given as the reason for the master's liability, it can hardly be imagined that any court would go so far as to hold the master at all times and under all circumstances for any misuse which the servant might make of it, after once giving the custody of the thing to him. The limitation upon the doctrine which it is desired to suggest is, that the master's liability is dependent upon whether the misuse of the dangerous instrument, which caused the damage, was such a misuse as might reasonably have been contemplated or expected by the master. And in considering this question, notice must be taken not only of the character of the thing with which the servant has been entrusted and the way in which it might be considered particularly dangerous, but also the place and manner of its use which is contemplated by the master, and the special temptations which the experience of mankind shows that there may be to misuse it, considering its character and the circumstances under which it is expected to be employed.

In all the cases which the courts have put squarely on the dangerous instrument doctrine, the element of play or mischief has entered into the misuse of the instrument rather than any actual evil intent to do injury because of some personal enmity or ill-will toward the person injured. It is true that the words "wilful" and "malicious" are used in many of the cases in describing the servant's conduct, having reference, however, only to the fact that the servant had no purpose of the master in view, and was actuated only by his own motives. ${ }^{15}$ The use of the

\footnotetext{
${ }^{16}$ Regan v. Reed (Igor) 96 Ill. App. $460 ; C . B . \&$ Q. R. R. Co. v. Dickson (1872) 63 Ill. I5I; Bittle v. Canten, etc., R. R. Co. (I893) 55 N. J. L. 615 .
} 
term "malice" in this connection seems to correspond with the definition given in an early slander case, where it was said: "Malice in common acceptation means ill will against a person, but in its legal sense it means a wrongful act, done intentionally, without just cause or excuse." ${ }^{16}$ In none of the cases does it appear that there was a preconceived and deliberately planned attempt to injure another, and that the masters' appliances were only used to carry out the agent's evil designs. It can hardly be imagined that any court would hold the master for such injuries done by a servant, though committed with the instruments of the master. If the master commits to a servant the care of a dangerous instrument which is particularly liable to playful misuse, why should he not be responsible when such a misuse as might reasonably have been anticipated has actually taken place and been the cause of an injury? It would seem that the dangerous instrument doctrine should be carried out only so far as the master had reason to contemplate such a misuse of the article, which has caused the injury for which he is sought to be held as a foreseeable result of the entrusting of such an instrument to his servant under the circumstances of the particular case.

Such a basis of liability may explain the result in a recent case, ${ }^{17}$ in which a railroad company having entrusted railroad torpedoes to its brakeman was held not to be liable for an injury which was brought about in the following manner: The brakeman to whom the torpedoes were entrusted, used one of them as a weight in order to throw a note to a young woman who lived near the right-of-way. It was picked up by a third person, carried into the house, and placed on the stove where it exploded and injured the plaintiff, the parties being ignorant of its dangerous character. The case was decided on the theory that the act was not within the scope of employment of the servant entrusted with the torpedo, though an earlier case in the same court ${ }^{16}$ seemed clearly to have established the dangerous instrument doctrine. The fact of entrusting the care of a thing to a servant as fixing the scope of his employment has long ago been done away with. But the result in the above case might be sustained on the reasoning previously suggested; namely, that

16 Bromage v. Prosser (1825) 4 B. \& C. 247.

${ }^{17}$ Johnson v. C. R. I. \& P. Ry. Co. (1913) 557 Ia. 738.

${ }^{18}$ Alsever v. M. \& St. L. Ry. Co. (1902) II5 Ia. 338. 
the master should not be held liable since the torpedo was not used by the person to whom it was entrusted in the manner in which it was dangerous. Any other weight would have done as well to accomplish the brakeman's purpose. He did not do this act because he had been entrusted with a dangerous instrument, nor was he attempting to make use of the dangerous qualities of the thing with which he had been entrusted. There was not such a misuse of the article as the railroad company in entrusting it to its servant could reasonably have anticipated because of its dangerous character.

This limitation on the master's liability, which would sustain such a result, was reached in the case of Obertoni v. B. \& $M$. $R . R{ }^{19}$ without discarding the whole dangerous instrument doctrine. Here a brakeman and a flagman used a signal torpedo to toss back and forth, and finally left it, where it was found by a boy who was injured by it. Here the dangerous qualities of the thing were not being made use of by the servant to whom the instrument had been entrusted. Whether it was thrown off of the defendant's right of way or not should not be decisive; $;^{20}$ for it would seem that the company should be held, had he thrown it off of the defendant's right of way, making use of it as an explosive; as, for instance, to frighten someone or attract his attention. He would, then, be making use of it in the manner in which it is particularly subject to misuse. How far away the servant might go from his place of employment and still bring a responsibility upon his master will be discussed later. But, in entrusting the servant with a dangerous instrument which is particularly subject to playful misuse, the master ought to be liable orily so far as the thing is used in the manner and under circumstances which might have been contemplated, or were reasonably to have been expected beforehand by reason of the peculiar quality of the thing. When the servant thus makes use of the dangerous propensities of the instrument with which the master has entrusted him, the master ought to be held liable for the injury which may result to third persons. So far as an injury caused by an instrument commonly called dangerous may be attributed to the negligence of the servant while acting within the scope of this employment, the ordinary doctrines of the law of master and servant in fixing a liability upon

19 (1904) I86 Mass. 48I.

${ }^{20}$ Cleveland, etc. R. R. Co. v. Marsh (1900) 63 Oh. St. 236. 
the master for the wrongful acts of the servant done within the scope of his employment, will take care of the case and the peculiar doctrine of dangerous instruments is not invoked.

In considering what sort of misuse may reasonably be contemplated, both the time and the place where the instrument is to be used should be considered. If a brakeman should take a railroad torpedo with which he had been entrusted to a lunchroom near the railway tracks and there misuse it as an explosive for some playful purpose, it is submitted that the railroad company should be liable for any injury resulting, while if he should take it with him to a dance or a picnic and cause an injury in a similar manner, the company should not be held. In the first case, the misuse is of a sort that may reasonably be expected, considering the nature of the thing and the time and place of its proper employment, while in the second case, the misuse is far beyond the mere temptation to misuse which might be brought about by the mere entrusting of the thing to the servant in this particular line of work. It shows too much of deliberate purpose of the servant, entirely unconnected with his employment and not necessarily or reasonably to be attributed to any temptation induced by entrusting him with the thing. One might buy a cannon cracker or other explosive and take it to the picnic, and the mere fact that the employment of the servant has made the securing of an explosive easy, should not connect the master with it in any such way as to bring a liability upon him for its misuse. The scope of the employment is important in this connection only for the purpose of determining the probable misuse which the master might have reason to expect that the servant might be tempted to make of the thing, because of the fact that he has been entrusted with it in his employment.

The place and character of the employment will have a very considerable bearing upon the temptation to misuse, since a certain misuse may be much more likely to occur in one employment than in another. This may to some extent explain the fact that the misuse of many of the appliances employed in the operation of railway trains are treated under the dangerous instrument doctrine, while the misuse of similar forces or appliances elsewhere will not subject the master to liability, even though the motive of the servant may be the same in the one case as in the other. ${ }^{21}$ By the very character of his employment, the railroad

${ }^{21}$ Canton etc. Co. v. Pool (Ig00) 78 Miss. I47. 
employee is removed from association and contact with people generally. This is particularly true of the engineer and fireman, and to a great degree also of the whole crew of a freight train. The somewhat solitary character of these employments as they exist for most of the men so engaged, and the fact that there may be considerable periods of idleness or inactivity, during which they are compelled to remain at their places of duty, may give temptation for the perpetration of playful pranks which would not be present to any such degree in other employments. The distinctions between the use of certain instrumentalities in connection with the operation of a steam railroad and a very similar use in other occupations, where such things are held not to be dangerous instruments and the master is not held to any liability when the servant has used them for a purpose of his own, must otherwise seem arbitrary. The suggestion that a different rule should be applied to railroads than to other corporations or individuals $^{22}$ is an astounding proposition for any court to suggest.

That the question of what is a dangerous instrument is, and must be, determined to a very considerable extent by the surroundings and circumstances under which the thing is intended to be used, seems apparent. It may be an arguable question whether anything may properly be spoken of an inherently dangerous $;^{23}$ for if so, then whatever is a dangerous instrument in one situation, would seem to be so under all circumstances. But a thing is dangerous only as it may require a particular amount of care to prevent it from doing harm, or, as applied to the particular situation under discussion, as there may be a special temptation to misuse it under the circumstances in which it is intended that it should be employed. It is difficult to see that there is anything more inherently dangerous about the whistle on a locomative than in the warning signal on an automobile, yet there may be a particular temptation for the engineer to misuse the one, so that this fact constitutes one of the perils which the master must answer for in entrusting it to his servant and employing it in his business, while there may be no particular temptation under the ordinary conditions of his employment for

${ }^{22}$ Stewart v. Cary Lumber Co. (1907) 146 N. C. 47; Bittle v. Camden, etc. R. R. Co. (1893) 55 N. J. L. 615; Nashville, etc. R. R. Co.v. Starnes (I87I) 9 Heisk. (Tenn.) 52.

23 Barmore v. Vicksburg, etc. Ry. Co. (I904) 85 Miss. 426. 
misuse on the part of the chauffeur who is entrusted with the warning signal of a motor car.

As has previously been pointed out, the cases in which a master has been held liable on the dangerous instrument doctrine have to do with some playful misuse of the instrument on the part of the servant. Under the theory here suggested, the motive of the servant in making a misuse of the instrument would be of supreme importance; for the master may have reason to expect a playful misuse of an attractive thing which he entrusts to his servant in a particular employment, while it could hardly be imagined that one could expect a deliberate perversion by the servant of the instrumentality entrusted to him in order to accomplish his own evil designs. If such a misuse were made, it can hardly be thought that it flowed from, or was in any way connected with the entrusting by the master, so that he had reason to expect such a misuse to be made. It can hardly be supposed that the servant did the act as a result of the entrusting by the master; for it is reasonable to suppose that he would have in some other way accomplished his evil purpose, even though the means might not have been as convenient. "Men are but boys grown tall." It is reasonable, therefore, to expect that a playful misuse of certain things may occur under certain circumstances and in certain occupations.

In considering the time and place where the wrongful act is done, the same test may be applied. The temptation to misuse the dangerous instrument may reasonably be expected at, or near the place where the servant is employed, and where he is supposed to use or have the custody of the thing. This is a peril quite directly connected with the work which the master has undertaken and for which he should be liable as one of the incidents of his business; for it is as much to be expected near the master's premises as actually upon them. If the mere entrusting alone does not fix an absolute responsibility upon the master for a misuse at any time or place, then it must be only for such misuse as might reasonably have been expected as incidental to the entrusting of the servant with the thing, and this must be judged by the character of the thing entrusted, together with the consideration of the time and place and the character of the employment in which it is to be used. The special and peculiar temptation to do so, and the experience of mankind must be called upon to determine whether certain instrumentalities or 
appliances are, under certain conditions or employments, peculiarly subject to playful or wanton misuse.

How far from the place of employment the servant may misuse the thing and still subject the master to liability cannot be told with exactness. There can be no definite measure for all cases. It is a question of degree. All through agency in determining, the difficult question of fact whether a servant is acting within or without the scope of his employment, we have no other test to go by. To tell how far from his place of employment the servant may misuse the dangerous instrument and still make his master liable, is a question not different in kind, and certainly no more difficult of solution, than to tell how far a servant would have to go, to change his acts from a mere detour into a "frolic of his own." It would seem arbitrary, if the master is to be held at all when the servant does the act for his own purpose, to limit his liability only when the acts are done on the master's property. The master ought to be held just as much when the brakeman who has been entrusted with a torpedo, takes it with him to a lunch-room near the tracks while his train is waiting on a siding, and there makes a playful misuse of its dangerous qualities, as if a similar misuse were made while sitting on the steps of the caboose on the company's premises. If the employee should take the torpedo with him to a dance in the evening and there explode it for the purpose of startling the dancers, it could hardly be supposed that the master's liability should be held to extend this far. To say that the master is relieved from liability because he has not entrusted the servant at this time and place, would fix a limitation upon the master's liability which would hold him only for acts done upon the company's property during working hours. It seems more reasonable to say that such a misuse was not so connected with the employment that the master had reason to expect it at such a time or place. The question which should determine the master's liability should be: Could the master have reasonably looked forward to and have expected such a misuse as incidental to entrusting this thing to the servant for use in the master's business?

It is submitted that no proper classification can be made of those things which are dangerous instruments and those which are not. ${ }^{24}$ Whether a thing is a dangerous instrument depends

24 Barmore v. Vicksburg, etc. Ry. Co. (I904) 85 Miss. 426. 
not alone on what are usually spoken of as its inherently dangerous qualities. But, considering the character and qualities of the thing, the important inquiry is: What is the temptation which there may be to misuse those qualities under the circumstances and conditions of the employment in which it is to be used? As has been pointed out, ${ }^{25}$ fire is probably as inherently dangerous as anything which a servant is given to handle, and yet it is doubtful if any court would hold a master liable for a misuse of it by a servant, unconnected with his master's business. The experience of mankind is such that there exists no special or unusual temptation to misuse it.

When, by this test, an instrument has been determined to be of such a dangerous character as to make the master liable for its misuse without reference to the principle respondeat superior, there is determined also the limitation which should be placed upon the liability of the master, $i$. $e$., those instruments are dangerous which, the experience of mankind has shown, specially tempt a servant in a particular line of employment to misuse, and the master should be held liable only in so far as the servant can be shown to have acted upon such temptation in the particular case.

StATE UNIVERSITY OF IOWA.

H. C. Horack.

${ }^{25}$ Ballard v. Louisville, etc. R. R. Co. (1908) $128 \mathrm{Ky} .826$. 